E3S Web of Conferences 1, 33003 (2013)

DOI: $10.1051 / \mathrm{e} 3 \operatorname{sconf} / 20130133003$

(C) Owned by the authors, published by EDP Sciences, 2013

\title{
Fractionation of $\mathrm{Cd}, \mathrm{Cu}, \mathrm{Ni}, \mathrm{Pb}$, and $\mathrm{Zn}$ in floodplain soils from Egypt, Germany and Greece
}

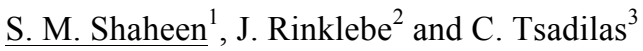 \\ ${ }^{1}$ Department of Soil \& Water Sciences, Faculty of Agriculture, University of Kafrelsheikh 33 516- Kafr El-Sheikh, \\ EGYPT, smshaheen1973@yahoo.com \\ ${ }^{2}$ Institute for Soil Engineering, Water- and Waste-Management, Soil- and Groundwater-Management, Department D, \\ University of Wuppertal, 42285 Wuppertal, GERMANY, rinklebe@uni-wuppertal.de \\ ${ }^{3}$ National Agricultural Research Foundation, Institute of Soil Mapping and Classification, 1 Theophrastos street, 41335 \\ Larissa, GREECE, tsadilas@lar.forthnet.gr
}

\begin{abstract}
Trace elements are potentially toxic to human life and the environment. Element toxicity depends on chemical associations in soils. Therefore, determining the chemical form of an element in soils is important to evaluate its mobility and bioavailability. Initial soil development in river floodplains influences soil properties, processes and therefore behavior of trace elements. In this study, three different floodplain soils sampled at three rivers (Nile/Egypt, Elbe/Germany and Penios/Greece) were used to link soil development and properties to the geochemical fractions and mobility of some trace elements. Sequential extraction was used to fractionate five trace elements $(\mathrm{Cd}, \mathrm{Cu}, \mathrm{Ni}, \mathrm{Pb}$ and $\mathrm{Zn})$ into five operationally defined groups: water soluble + exchangeable, carbonate, Fe-Mn oxide, organic, and residual. German soil showed the highest total concentration of the studied elements (except Ni). The Greek soil had the greatest amount of Ni. The residual fraction was the abundant pool for the studied elements examined in the Egyptian and Greek soils while the non-residual fraction was the dominant pool for all elements in the German soil. A significant amount (7194\%) of all elements was present in German soil in the potentially available fraction: non-residual fraction, while the amount of this fraction ranged between 9 and $39 \%$ in Greek soil and between 9 and $34 \%$ in Egyptian soil. These suggest that the potential availability of the studied trace elements was extremely high in German soil compared to the Egyptian and Greek soil. In the German soil, most of the non-residual Cd, Ni and $\mathrm{Zn}$ were bounded with the $\mathrm{Fe}-\mathrm{Mn}$ oxide fraction, while $\mathrm{Cu}$ and $\mathrm{Pb}$ distributed in the organic fraction. While in the Egyptian and Greek soils Fe-Mn oxide fraction was the abundant pool for the studied elements except for $\mathrm{Cd}$, in which the exchangeable and the carbonate fractions had the greatest amount of $\mathrm{Cd}$. Assuming that mobility and bioavailability of these elements are related to their solubility and geochemical forms, and that they decrease in the order of extraction sequence, the apparent mobility and potential bioavailability for the studied elements in the soils were: $\mathrm{Cu}>\mathrm{Cd}>\mathrm{Ni} \geq \mathrm{Pb}=\mathrm{Zn}$ in Egyptian soil, $\mathrm{Cd}>\mathrm{Cu}>\mathrm{Pb}>\mathrm{Ni}=\mathrm{Zn}$ in Greek soil and $\mathrm{Cd}>\mathrm{Zn}>\mathrm{Pb}>\mathrm{Cu}>\mathrm{Ni}$ in German soil.
\end{abstract}

Key Words: Trace Elements; Speciation; Potential Availability; Floodplain Soils

\section{Introduction}

Trace elements, such as $\mathrm{Cd}, \mathrm{Cu}, \mathrm{Ni}, \mathrm{Pb}$ and $\mathrm{Zn}$, are potential soil pollutants. Soils consist of heterogeneous mixtures of organic and inorganic solid components as well as a variety of soluble substances. Therefore, metal distribution among specific forms varies widely based on the metal's chemical properties and soil characteristics (Hooda, 2010). Thus, it is important to evaluate the mobility of trace elements to establish environmental guidelines for potential toxic hazards and to understand chemical behavior and fate of trace elements in soils (Singh et al. 2005). The evaluation of metal distribution in the various organic and mineral phases found in soils may be more useful for the prediction of metal behavior, including solubility, mobility, bioavailability and thus toxicity (Kapata-Pendias, 2011). It is, therefore, important to find appropriate extraction methods for the quantification of elements bound to specific phases of soils. Therefore, sequential extraction procedures were developed aiming to predict retention, mobility and bioavailability of trace elements in soils. The agricultural 
floodplain soils of Egypt, Germany and Greece differ widely in their origin, development and properties and therefore it is expected trace elements content and its distribution among the different chemical fractions differ also widely (Du Laing et al. 2009). Our objective was to investigate concentrations of total $\mathrm{Cd}, \mathrm{Cu}, \mathrm{Ni}, \mathrm{Pb}$, and $\mathrm{Zn}$ elements and their speciation in the different chemical fractions in three soil samples representing the fluvial sediments of the rivers Nile, Elbe, and Penios in relation to the basic soil properties.

\section{Materials and Methods}

\section{Soil selection and characterization}

Three surface soil samples were selected from the floodplain close to the rivers Nile, Elbe and Penios representing the fluvial soils in Egypt, Germany and Greece. The selected samples, air-dried, ground to pass through a 2-mm sieve and analyzed for their basic physical and chemical properties according to the procedures referred by Sparks et al. (1996). Total free iron oxides $\left(\mathrm{Fe}_{\mathrm{d}}\right)$ were extracted with $3 \mathrm{M}$ sodium citrate + $1 \mathrm{M}$ sodium bicarbonate $+1 \mathrm{~g}$ sodium dithionite in a water bath heated at $85 \mathrm{C}^{\mathrm{o}}$ (Mehra and Jackson, 1960). Associated $\mathrm{Al}$ and $\mathrm{Mn}$ measured in the same extracts.. Some properties of the studied soils are presented in Table 1. Total elements form was digested and extracted using $\mathrm{HNO}_{3}+\mathrm{HCL}+\mathrm{H}_{2} \mathrm{O}_{2}$ according to USEPA (1995).

Table 1.Classification and selected properties of the studied soils

\begin{tabular}{|c|c|c|c|}
\hline Characteristics & $\begin{array}{l}\text { Egyptian } \\
\text { soil } \\
\end{array}$ & $\begin{array}{c}\text { Greek } \\
\text { soil }\end{array}$ & $\begin{array}{c}\text { German } \\
\text { soil }\end{array}$ \\
\hline Classification & $\begin{array}{c}\text { Typic } \\
\text { Ustifluvent }\end{array}$ & $\begin{array}{c}\text { Typic } \\
\text { Xerofluvent }\end{array}$ & $\begin{array}{c}\text { Typic } \\
\text { Ustifluvent } \\
\end{array}$ \\
\hline \multicolumn{4}{|c|}{ Particle size distribution, $\%$} \\
\hline Sand & 12 & 75 & 31 \\
\hline Silt & 41 & 16 & 43 \\
\hline Clay & 47 & 9 & 26 \\
\hline \multicolumn{4}{|c|}{ Tested Basic characteristics } \\
\hline $\mathrm{pH}$ & 7.87 & 7.75 & 6.98 \\
\hline $\mathrm{EC}$ & 782.0 & 184.5 & 221.0 \\
\hline OM, $\%$ & 1.86 & 1.31 & 16.1 \\
\hline $\mathrm{CEC}$ & 72.1 & 13.6 & 35.9 \\
\hline $\mathrm{CaCO}_{3}, \%$ & 1.5 & 10.45 & 0 \\
\hline \multicolumn{4}{|c|}{ CBD-extracted oxides, $\mathrm{g} \mathrm{kg}^{-1}$} \\
\hline $\mathrm{Fe}$ & 10.8 & 2.96 & 19.0 \\
\hline Mn & 0.92 & 0.25 & 8.9 \\
\hline Al & 0.89 & 0.23 & - \\
\hline \multicolumn{4}{|c|}{ Oxalate-extracted oxides, $\mathrm{g} \mathrm{kg}^{-1}$} \\
\hline $\mathrm{Fe}$ & 2.54 & 1.12 & 18.2 \\
\hline $\mathrm{Mn}$ & 0.78 & 0.19 & 0.60 \\
\hline $\mathrm{Al}$ & 1.86 & 0.8 & - \\
\hline
\end{tabular}

pH $\left(1: 1 \mathrm{H}_{2} \mathrm{O}\right)$; EC; Electric conductivity $(\mu \mathrm{S} / \mathrm{cm})$; OM: Organic matter; CEC: Cation Exchange Capacity $(\mathrm{cmol}(+) / \mathrm{kg}) ; \mathrm{Fe}_{\mathrm{d}}, \mathrm{Al}_{\mathrm{d}}, \mathrm{Mn}_{\mathrm{d}}$ : Citratebicarbonate-dithionate extractable- $\mathrm{Fe}, \mathrm{Al}, \mathrm{Mn} ; \mathrm{Fe}_{\mathrm{o}}, \mathrm{Al}_{0}, \mathrm{Mn}_{\mathrm{o}}$ Ammonium oxalate-oxalic acid extractable- $\mathrm{Fe}, \mathrm{Al}, \mathrm{Mn}$ nd: not detected; (-): not measured

\section{Fractionation of trace elements in Egyptian and Greek} soil samples

The chemical forms of the metals were determined by a sequential extraction method or five-step chemical fractionation based on the work of Tessier et al. (1979) and proposed by Elliott et al. (1990), Sánchez-Martín et al., (2007) and Shaheen and Tsadilas (2011) to characterize the partitioning of trace metals in studied soils. The method used discriminates the metals into water soluble and exchangeable (F1: $1 \mathrm{M} \mathrm{NH}_{4} \mathrm{OAc}(\mathrm{pH}$ 7.0 ), easily mobilizable or carbonate bound (F2: $1 \mathrm{M}$ $\mathrm{NH}_{4} \mathrm{OAc}$ adjusted to $\mathrm{pH} 5$ with $\left.\mathrm{HOAc}\right), \mathrm{Fe}-\mathrm{Mn}$ oxide bound (F3: $0.175 \mathrm{M}\left(\mathrm{NH}_{4}\right)_{2} \mathrm{C}_{2} \mathrm{O}_{4}$ and $0.1 \mathrm{M} \mathrm{H}_{2} \mathrm{C}_{2} \mathrm{O}_{4}$ ), organically bound (F4: $0.1 \mathrm{M} \mathrm{Na}_{4} \mathrm{P}_{2} \mathrm{O}_{7}$ ), an F5: residual fraction $=$ total concentration minus $\Sigma \mathrm{F}$ 1 to $\mathrm{F} 4$. Separation between steps was by decantation of the supernatant after centrifugation at $5000 \mathrm{rpm}$ for $20 \mathrm{~min}$. Metal and oxides concentrations of samples were determined using an atomic absorption spectrometry (Varian, SpectrAA-400 Plus, Australia).

\section{Fractionation of trace elements German soil samples}

The soil samples were sequentially extracted to obtain the seven fractions of $\mathrm{Cd}, \mathrm{Cu}, \mathrm{Ni}, \mathrm{Pb}$ and $\mathrm{Zn}$ (Zeien and Brummer 1989). Briefly, $2 \mathrm{~g}$ of air dried soil $(<2 \mathrm{~mm})$ and $50 \mathrm{~mL}$ extracting agent were shaken (over head 20 rotations $\mathrm{min}^{-1}$ ) at $20^{\circ} \mathrm{C}$. The samples were centrifuged for $10 \mathrm{~min}$ at $3000 \mathrm{x} \mathrm{g}$ and filtered. The extracting agents and common interpretation of fractions are as follows:

F1: $1 \mathrm{M} \mathrm{NH}_{4} \mathrm{NO}_{3}$ (mobile fraction), F2: $1 \mathrm{M} \mathrm{NH}_{4}$-acetate (easily mobilizable fraction), F3: $0.1 \mathrm{M}\left[\mathrm{NH}_{3}(\mathrm{OH})\right] \mathrm{Cl}+$ $1 \mathrm{M} \mathrm{NH}_{4}$-acetat (bound to Mn (hydr)oxides), F4: 0.025 $\mathrm{M} \mathrm{NH}_{4}$-EDTA (bound to soil organic matter (SOM)), F5: $0.2 \mathrm{M} \mathrm{NH}_{4}$-oxalate buffer (bound by low crystalline Fe (hydr)oxides), F6: $0.2 \mathrm{M} \mathrm{NH} \mathrm{NH}_{4}$-oxalate buffer + ascorbic acid (bound by crystalline Fe (hydr) oxides), F7: residual fraction $=$ total concentration minus $\Sigma \mathrm{F} 1$ to $\mathrm{F} 6$. The whole pool of Fe-Mn oxide fraction in the tabled data calculated from the summation of F3, F5 and F6 and presented as F3. The metal concentrations were determined by inductively coupled plasma-optical emission spectroscopy (ICP-OES, JY 238, Jobin Yvon, France).

\section{Results and Discussion}

The sequential extraction is useful to assess the potential mobility and bioavailability of heavy metals in the soils. The chemical fractions are operationally defined). Assuming that bioavailability is related to solubility, then metal bioavailability decreases in the order: water soluble $>$ exchangeable $>$ carbonate $>$ Fe-Mn oxide $>$ organic $>$ residual (Ma and Rao, 1997). This order is just a generalization and offers qualitative information about metal bioavailability. Based on the above information, we can further assume that metals in the non-residual fractions are more bioavailable than metals associated with the residual fraction. The non-residual fraction is the sum of all fractions except the residual fraction.

\section{Cadmium}

The three studied soils showed high variation in the total concentration and distribution of $\mathrm{Cd}$ among the different fractions. German soil contained high concentration of 
total $\mathrm{Cd}\left(7.9 \mathrm{mg} \mathrm{kg}^{-1}\right)$ and was highly contaminated compared to the Egyptian $\left(1.7 \mathrm{mg} \mathrm{kg}^{-1}\right)$ and Greek soil $\left(1.5 \mathrm{mg} \mathrm{kg}^{-1}\right)$. In the Egyptian and Greek soils, Cd was mostly concentrated in the residual fraction, while in the German soil it was concentrated in the non residual fractions (Table 2). The percentage of total $\mathrm{Cd}$ in the residual fraction were $6.3,61.3$ and $81.8 \%$ in German, Greek and Egyptian soils respectively. These data mean that, in the German soil the percentage of $\mathrm{Cd}$ in the nonresidual fractions was much greater than that of the residual fractions.

Table 2: Chemical fractions of studied elements in fluvial sediments from Egypt, Germany and Greece

\begin{tabular}{|c|c|c|c|c|c|c|}
\hline \multirow{2}{*}{$\begin{array}{c}\text { Fractio } \\
\text { ns }\end{array}$} & \multicolumn{2}{|c|}{$\begin{array}{l}\text { Egyptian } \\
\text { floodplain }\end{array}$} & \multicolumn{2}{|c|}{$\begin{array}{c}\text { Greek } \\
\text { floodplain }\end{array}$} & \multicolumn{2}{|c|}{$\begin{array}{l}\text { Germanic } \\
\text { floodplain }\end{array}$} \\
\hline & $\begin{array}{l}\mathrm{mg} \\
\mathrm{kg}^{-1}\end{array}$ & $\begin{array}{l}\% \text { of } \\
\text { total }\end{array}$ & $\begin{array}{c}\mathrm{mg} \\
\mathrm{kg}^{-1} \\
\mathrm{Cd}\end{array}$ & $\begin{array}{l}\% \text { of } \\
\text { total }\end{array}$ & $\begin{array}{l}\mathrm{mg} \\
\mathrm{kg}^{-1}\end{array}$ & $\begin{array}{l}\% \text { of } \\
\text { total }\end{array}$ \\
\hline F1 & 0.15 & 8.8 & 0.02 & 1.3 & 0.1 & 1.3 \\
\hline F2 & 0.12 & 7.1 & 0.35 & 23.3 & 2.2 & 27.8 \\
\hline F3 & 0.04 & 2.4 & 0.21 & 14.0 & 2.7 & 34.1 \\
\hline F4 & 0.00 & 0.0 & 0.00 & 0.0 & 2.4 & 30.3 \\
\hline F5 & 1.39 & 81.7 & 0.92 & 61.3 & 0.5 & 6.3 \\
\hline Total & 1.70 & & 1.50 & & 7.9 & \\
\hline \multicolumn{7}{|c|}{$\mathrm{Cu}$} \\
\hline F1 & 0.14 & 0.21 & 0.11 & 0.37 & 1.9 & 1.1 \\
\hline $\mathrm{F} 2$ & 0.17 & 0.26 & 0.23 & 0.77 & 3.0 & 1.8 \\
\hline F3 & 18.5 & 28.1 & 9.3 & 31.2 & 31.9 & 18.9 \\
\hline F4 & 3.3 & 4.9 & 1.3 & 4.5 & 99.6 & 59.1 \\
\hline F5 & 43.7 & 66.6 & 18.9 & 63.5 & 32.0 & 19.0 \\
\hline Total & 65.6 & & 29.7 & & 168. & \\
\hline \multicolumn{7}{|c|}{$\mathrm{Ni}$} \\
\hline F1 & 0.27 & 0.37 & 0.15 & 0.06 & 0.2 & 0.30 \\
\hline F2 & 0.43 & 0.60 & 1.27 & 0.55 & 1.3 & 1.95 \\
\hline F3 & 6.58 & 9.18 & 14.0 & 6.06 & 34.2 & 51.3 \\
\hline F4 & 0.58 & 0.81 & 4.43 & 1.91 & 11.3 & 16.9 \\
\hline F5 & 63.7 & 89.0 & 212. & 91.4 & 19.6 & 29.4 \\
\hline Total & 71.6 & & 232. & & 66.6 & \\
\hline \multicolumn{7}{|c|}{$\mathrm{Pb}$} \\
\hline F1 & 1.06 & 3.84 & 0.38 & 1.79 & 0.5 & 0.50 \\
\hline F2 & 0.48 & 1.75 & 2.05 & 9.53 & 1.3 & 1.29 \\
\hline F3 & 1.20 & 4.36 & 1.12 & 5.21 & 25.8 & 25.6 \\
\hline F4 & 0.00 & 0.00 & 0.72 & 3.35 & 57.7 & 57.2 \\
\hline F5 & 24.7 & 90.0 & 17.2 & 80.1 & 15.5 & 15.3 \\
\hline Total & 27.5 & & 21.5 & & 100. & \\
\hline \multicolumn{7}{|c|}{$\mathrm{Zn}$} \\
\hline F1 & 0.14 & 0.15 & 0.07 & 0.17 & 9.5 & 1.10 \\
\hline $\mathrm{F} 2$ & 0.28 & 0.31 & 0.27 & 0.62 & 87.6 & 10.2 \\
\hline F3 & 6.51 & 7.16 & 2.83 & 6.59 & 453 & 52.7 \\
\hline F4 & 1.58 & 1.73 & 0.56 & 1.30 & 214 & 24.9 \\
\hline F5 & 82.4 & 90.6 & 39.2 & 91.3 & 96.3 & 11.1 \\
\hline Total & 90.9 & & 43.0 & & 861 & \\
\hline
\end{tabular}

F1: water soluble and exchangeable; F2: carbonate bound; F3: Fe-Mn oxide bound; F4: organically bound; F5: residual fraction; $\sum$ F1-F4: nonresidual fraction

Among the nonresidual fractions, the Fe-Mn oxide fraction contained the greatest amount of $\mathrm{Cd}$ in German soil compared to the Egyptian and Greek soils, in which the soluble + exchangeable and the carbonate fractions, respectively, had the greatest amount of $\mathrm{Cd}$ (Table 2). Also, data showed that about $30 \%$ of the total Cd was distributed in the organic fraction, while the same fraction was not detected in the Egyptian and Greek soils. In this respect, Lair et al. (2008) studied distribution of cadmium among geochemical fractions in floodplain soils of progressing development and reported that cadmium remained in weakly bound fractions in both original and spiked soils. Increasing the non residual fraction in German soil compared to the Egyptian and Greek soils suggests that $\mathrm{Cd}$ in this German soil was potentially bioavailable because the metals present in the exchangeable fraction are usually thought to be readily available for plant uptake.

\section{Copper}

German soil contained high concentration of total $\mathrm{Cu}$ (168.4 $\mathrm{mg} \mathrm{kg}^{-1}$ ) compared to the Egyptian (65.6 $\left.\mathrm{mg} \mathrm{kg}^{-1}\right)$ and Greek soil $\left(29.7 \mathrm{mg} \mathrm{kg}^{-1}\right)$. Like, Cd most of the $\mathrm{Cu}$ in the Egyptian and Greek soil soils was present in the residual fraction ( $>63 \%$ ), while only $19 \%$ of the total $\mathrm{Cu}$ was fractionated in the residual fraction in German soil. Ma and Rao (1997) found a majority of the $\mathrm{Cu}$ in soils and sediments to be associated with the residual fraction. Although $\mathrm{Cu}$ was found in all non residual fractions in the three soils, a small percentage of $\mathrm{Cu}$ $(0.47-1.8 \%)$ was associated with the water soluble+exchangeable and carbonate fractions, while FeMn oxide fraction was the dominant non residual in the Egyptian and Greek soil soils and the organic fraction was the dominant one in German soil. In the case of German soil, the greatest percentage of $\mathrm{Cu}$ was associated with the organic fraction (59\%) due to the high organic carbon content. Although $\mathrm{Cu}$ was found in all non residual fractions in the three soils, it was mostly concentrated in the Fe-Mn oxide fraction in the Egyptian and Greek soils. Our results were consistent with that of $\mathrm{Ma}$ and Rao (1997) who found significant amount of $\mathrm{Cu}$ in soils associated with the organic fraction. The major association of $\mathrm{Cu}$ with the organic fraction in these soil may be due to high formation constants of organic- $\mathrm{Cu}$ complexes. As the total $\mathrm{Cu}$ concentration in the German soils increased, the percent of total $\mathrm{Cu}$ in the water soluble + exchangeable, carbonate, and organic fractions increased and $\mathrm{Cu}$ in the Fe-Mn oxide and residual fractions decreased. This suggests that as the extent of $\mathrm{Cu}$ contamination in soils increased, more $\mathrm{Cu}$ was associated with the nonresidual fractions, which increased potential $\mathrm{Cu}$ mobility and bioavailability in these soils.

\section{Nickel}

Unlike the other tested elements, German soil showed lower concentration of total $\mathrm{Ni}$ than the Egyptian and Greek soil (Table 2). However, like, $\mathrm{Cd}$ and $\mathrm{Cu}$, most of the total $\mathrm{Ni}$ in the Egyptian and Greek soil soils was present in the residual fraction ( $>89 \%$ ), while only $29 \%$ of the total $\mathrm{Ni}$ was fractionated in the residual fraction in German soil. These results are consistent with the observations of Tessier et al. (1980), who suggested that a majority of the $\mathrm{Ni}$ in soils and sediments was detrital in nature. The Fe-Mn oxide fraction was the dominant non residual fraction in all three soils by a percent around 51, 9 and $6 \%$ of total $\mathrm{Ni}$ in German, Egyptian and Greek soils respectively.

\section{Lead}

German soil contained high concentration of total $\mathrm{Pb}$ (100.8 $\left.\mathrm{mg} \mathrm{kg}^{-1}\right)$ compared to the Egyptian $\left(27.5 \mathrm{mg} \mathrm{kg}^{-1}\right)$ and Greek soil $\left(21.5 \mathrm{mg} \mathrm{kg}^{-1}\right)$. In the Egyptian and Greek soils, $\mathrm{Pb}$ was mostly concentrated in the residual fraction, 
while in the German soil it was concentrated in the non residual fractions (Table 2). The percentage of total $\mathrm{Pb}$ in the residual fraction were $15.3,80.1$ and $90.1 \%$ in German, Greek and Egyptian soils respectively. Among the nonresidual fractions, the organic fraction contained the greatest amount of $\mathrm{Pb}$ in German soil (57\%) followed by Fe-Mn oxide (25\%) compared to the Egyptian and Greek soils, in which the Fe-Mn oxide and carbonate fraction, respectively, had the greatest amount of $\mathrm{Pb}$.

\section{Zinc}

Total concentration of $\mathrm{Zn}$ in German soil $\left(862 \mathrm{mg} \mathrm{kg}^{-1}\right)$ was higher than Egyptian $\left(91 \mathrm{mg} \mathrm{kg}^{-1}\right)$ and Greek soils $\left(43 \mathrm{mg} \mathrm{kg}^{-1}\right)$. The normal $\mathrm{Zn}$ concentration in soils is 70 to $400 \mathrm{mg} \mathrm{kg}^{-1}$ (Kabata-Pendias, 2011). These data showed that, the Egyptian and Greek soil were not contaminated with $\mathrm{Cu}$, whereas the German soil was contaminated with $\mathrm{Zn}$. Like the other elements, in the Egyptian and Greek soils, Zn was mostly concentrated in the residual fraction; while in the German soil was concentrated in the non residual fractions (Table 2). The percentage of total $\mathrm{Zn}$ in the residual fraction were 11.2, 90.6 and $91.3 \%$ in German, Egyptian and Greek soils respectively. Among the nonresidual fractions, the Fe-Mn oxide contained the greatest amount of $\mathrm{Pb}$ in all soils containing about $53 \%$ in German soil, and $7 \%$ in the Egyptian and Greek soils.

\section{Conclusion}

A sequential extraction procedure was used to fractionate $\mathrm{Cd}, \mathrm{Cu}, \mathrm{Ni}, \mathrm{Pb}$ and $\mathrm{Zn}$ present in three surface floodplain soil samples close to the rivers Nile, Elbe and Penios in Egypt, Germany and Greece. Different geochemical fractions are operationally defined by an extraction sequence that generally follows the order of decreasing solubility. The residual fraction was the abundant pool (61-91\%) for the studied elements examined in the Egyptian and Greek studied soils. However, in German soil, a significant percentage (71-94\%) of total elements was associated with the nonresidual fractions. Therefore, they should be evaluated when studying the pollution levels of heavy metals in soils. These results suggest that the potential availability of the studied trace elements was extremely high in German soil compared to the both other. A major portion (36-80\%) of $\mathrm{Cu}$ and (19-94\%) of $\mathrm{Cd}$ was associated with the organic, Fe-Mn oxide, and carbonate fractions in the soils studied, indicating that this metals was potentially more bioavailable than other elements examined. Among the three soils tested, German soil were the most contaminated soils with the five trace elements studied.

\section{References}

Du Laing G, Rinklebe J, Vandecasteele V, Meers E, Tack FM. Trace metal behaviour in estuarine and riverine floodplain soils and sediments: A review. Sci Total Environ 2009; 407: 3972-3985.

Elliott HA, Dempsey BA, Maille MJ. Content and fractionation of heavy-metals in water treatment sludges; J. Environ. Qual 1990; 19: 330-334.

Hooda PS. Trace elements in soils. First ed. John Wiley \& Sons Ltd, The Atrium, Southern Gate, Chichester, West Sussex, PO19 8SQ, United Kingdom. 2010.

Kabata-Pendias A. Trace Elements in Soils and Plants, fourth ed. CRC Press, Boca Raton, USA, 2011.

Lair G, Graf, M. Zehetner F. Gerzabek M.. Distribution of cadmium among geochemical fractions in floodplain soils of progressing development Environmental Pollution 2008; 156: 207-214.

Loeppert RH, Inskeep WP. Iron, In: D.L. Sparks, (Ed.), Methods of Soil Analysis: Chemical Methods, Part 3. ASA and SSSA, Madison, WI, .1996. pp. 639-664.

$\mathrm{Ma}$, LQ and Rao, GN. Chemical fractionation of cadmium, copper, nickel and zinc in contaminated soils. J Environ Qual. 1997: 26: 259-264.

Mehra OP, Jackson ML. Iron oxides removal from soils and clays by dithionate-citrate system buffered with sodium bicarbonate. In: Clays and Clay Minerals. Proc. 7th Natl. Congr. Pergamon, London, 1960. pp. 317327.

Sánchez-Martín, M., M. García-Delgado., L. Lorenzo., M. Rodríguez-Cruz., M. Arienzo. Heavy metals in sewage sludge amended soils determined by sequential extractions as a function of incubation time of soils. Geoderma 2007: 142 :262-273.

Shaheen SM, CD Tsadilas. Fractionation and bioavailability of trace elements in biosolid amended alfisol ten years after biosolids application. $11^{\text {th }}$ ICOBTE. Florence, Italy, 2011; July 3-7.

Singh K, Mohan D, Singh V, Malik A. Studies on distribution and fractionation of heavy metals in Gomti river sediments - a tributary of the Ganges, India. Journal of Hydrology 2005; 312: 14-27.

Sparks D L (Ed) Methods of Soil Analysis: Chemical Methods, Part 3. ASA and SSSA, Madison, WI. 1996

Tessier A, Campbell P, Bosson M. Sequential extraction procedure for speciation of particulate trace elements.Analyt.Chemist.1979;51:844-851.

United States Environmental Protection Agency (USEPA). Test methods for evaluating solid wastes. USEPA SW 846. U.S. Gov. Print. Office, Washington DC. 1995.

Zeien H, Brummer GW. Chemische Extraktion zur Bestimmung von Schwermetallbindungsformen in Boden. Mitt. Dtsch. Bodenkundl. Ges. 1989; 59: 505510. 